BBA 65045

\title{
GLUTAMINE SYNTHETASE
}

\section{DEPENDENCE OF ITS SULFHYDRYL REQUIREMENT ON ORGANIC LIGANDS AND METAL IONS*}

\author{
CHUNG WU \\ Department of Internal Medicine, The University of Michigan, \\ Ann Arbor, Mich. (U.S.A.)
}

(Received December 27th, I963)

\begin{abstract}
SUMMARY
A partially purified preparation of glutamine synthetase (L-glutamate: ammonia ligase (ADP), EC 6.3.I.2) has been obtained from rat liver. The enzyme preparation showed no activity in the absence of $\mathrm{Mg}^{2+} ; \mathrm{Mn}^{2+}$ could not replace $\mathrm{Mg}^{2+}$. $\mathrm{Mn}^{2+}$ exhibited a slight activation of the enzyme at low $\mathrm{Mg}^{2+}$ concentrations, but a pronounced inhibition at high $\mathrm{Mg}^{2+}$ concentrations. The inhibition by a number of metal ions including $\mathrm{Fe}^{2+}, \mathrm{Fe}^{3+}, \mathrm{Co}^{2+}, \mathrm{Cu}^{2+}, \mathrm{Cu}^{+}, \mathrm{Zn}^{2+}, \mathrm{Cd}^{2+}$, and $\mathrm{Hg}^{2+}$ depended on the concentration of a thiol. The enzyme showed a partial requirement for a thiol, which could be abolished by certain organic ligands. Among them the most effective were EDTA, hydroxyethylethylenediaminetriacetate, nitrilotriacetate, and I, ro-phenanthroline.

Sodium arsenite inhibited the synthetase only in the presence of an active dithiol such as 2,3-dimercaptopropanol, but the inhibition could be reversed by an excess of the dithiol. $p$-Chloromercuribenzoate, iodoacetate, $o$-iodosobenzoate and $N$-ethylmaleimide exerted different degrees of inhibition on the enzyme. The synthetase was also sensitive to formamidine disulfide. Antecedent incubation of the enzyme with the inhibitor greatly enhanced the potency of the inhibitor and consequently required a large excess of 2,3-dimercaptopropanol to restore the enzyme activity.

These results have been interpreted to mean that glutamine synthetase may contain a metal ion and a dithiol component.
\end{abstract}

\section{INTRODUCTION}

The enzymic synthesis of glutamine from glutamate requires, in addition to the substrates, a thiol and a metal ion. Although the partial requirement for a thiol can usually be met by cysteine ${ }^{2}$ or 2 -mercaptoethanol ${ }^{3}, \mathrm{BAL}$ is considerably more active than either compound for glutamine synthetase (L-glutamate: ammonia ligase (ADP), EC 6.3.I.2) in rat liver ${ }^{4}$. The reaction requires $\mathrm{Mg}^{2+}$ (see ref. 5), but various degrees of activation by $\mathrm{Mn}^{2+}$ have been observed for the enzyme from different sources ${ }^{2,6-10}$.

With a partially purified enzyme preparation from rat liver, the author has disulfide.

Abbreviations: HEDTA, hydroxyethylethylenediaminetriacetate; FDS, formamidine

* Paper IV of this series described the formation of glutamine synthetase in rat liver during mitotic and non-mitotic growth1. 
observed that the presence of certain metal ions affects the sulfhydryl requirement of the enzyme, and that certain ligands can abolish this requirement. $\mathrm{Mn}^{2+}$ can either activate the enzyme or inhibit it, depending on the $\mathrm{Mg}^{2+}$ concentration. Moreover, a thiol-dependent inhibition of the enzyme has been demonstrated. This report presents these results and their implications.

\section{EXPERIMENTAL PROCEDURE}

Precautions have been taken to protect the system from contamination with metals. All glassware was soaked in a concentrated $\mathrm{H}_{2} \mathrm{SO}_{4}-\mathrm{HNO}_{3}$ mixture and thoroughly rinsed with distilled water and finally with demineralized water having a specific resistance of $10^{6} \mathrm{ohms}$. The demineralized water also served for preparing all reagents, for assaying the enzyme activity, and in the purification procedure. For the purposes of this investigation, thiols and strong ligands were excluded during purification of the enzyme.

\section{Purification of the enzyme}

A partially purified glutamine synthetase preparation has been obtained from rat liver by the following procedure. Rat liver $(25 \mathrm{~g})$ was cut coarsely in cold $0.25 \mathrm{M}$ sucrose with a pair of stainless steel scissors. An all-glass homogenizer served to make a homogenate containing $20 \mathrm{~g}$ liver/roo $\mathrm{ml}$. All subsequent operations were carried out at $5^{\circ}$. The homogenate ( $125 \mathrm{ml}$ ) was centrifuged at 105 ooo $\times \mathrm{g}$ for $60 \mathrm{~min}$ in a Spinco Model L ultracentrifuge. The supernatant fluid (usually I03 $\mathrm{ml}$ ) was discarded. The pellet was lightly homogenized in I03 $\mathrm{ml}$ of a $0.25 \mathrm{M}$ sucrose containing $0.4 \mathrm{M} \mathrm{NaCl}$. The suspension was similarly centrifuged. The supernatant fluid containing nearly all the enzyme activity was collected. This initial step in the purification procedure made use of an earlier observation ${ }^{11}$ that, although the synthetase activity in the rat liver remained in the pellet after centrifuging at $105000 \times g$ for $60 \mathrm{~min}$, it could be solubilized with dilute $\mathrm{NaCl}$ solution.

Solid $\left(\mathrm{NH}_{4}\right)_{2} \mathrm{SO}_{4}$ was added with constant stirring to $103 \mathrm{ml}$ of the $\mathrm{NaCl}$ extract to $\mathrm{I}_{5} \%$ saturation. The suspension was centrifuged at ro ooo $\times g$ for Io min. Solid $\left(\mathrm{NH}_{4}\right)_{2} \mathrm{SO}_{4}$ was again added to the supernatant fluid to a final $37 \%$ saturation. The suspension likewise centrifuged. The pellet was dissolved in about $25 \mathrm{ml}$ of o.or M Tris buffer ( $\mathrm{pH} 7.2$ ); the total volume measured $30.8 \mathrm{ml}$.

The $\mathrm{pH}$ of the enzyme solution was adjusted to 4.9 by adding dropwise $0.5 \mathrm{M}$ acetic acid. The cloudy suspension was centrifuged as in the last step. The supernatant fluid was similarly adjusted to $\mathrm{pH}_{4.2}$ and centrifuged again. About $8 \mathrm{ml}$ of $0.05 \mathrm{M}$ Tris buffer ( $\mathrm{pH}$ 7.6) served to extract the enzyme activity from the pellet by constant stirring for $30 \mathrm{~min}$; the suspension was centrifuged. The pellet was extracted in the same way once more. The combined supernatant fluid measured $15.2 \mathrm{ml}$.

The enzyme solution from the preceding step was dialyzed for $3 \mathrm{~h}$ against two changes of $400 \mathrm{ml}$ each of $5 \mathrm{mM}$ Tris buffer at $\mathrm{pH}$ 7.2. The dialysate had a volume of I6.I $\mathrm{ml}$. The enzyme preparation obtained after the dialysis was used in all experiments reported in this study.

\section{Enzymic assays}

A procedure described in detail elsewhere ${ }^{4}$ and slightly modified ${ }^{1}$ served for $^{-}$ 
determining the synthetase activity. The definition for one unit of the enzyme activity has been given ${ }^{1} \cdot \gamma$-Glutamyltransferase activity was assayed as follows: Into a small Erlenmeyer flask were added 0.25 mmole of L-glutamine, 0.20 mmole of $\mathrm{NH}_{2} \mathrm{OH} \cdot \mathrm{HCl}$ (freshly neutralized to $\mathrm{pH} 5.9$ with $\mathrm{NaOH}$ ), $8 \mu$ moles of $\mathrm{MnCl}_{2}, 0.5 \mu$ mole of adenosine diphosphate (lithium salt), $50 \mu$ moles of phosphate buffer ( $\mathrm{pH}_{5} .9$ ), enzyme, and water to a final volume of $4.5 \mathrm{ml}$. A similar flask containing all the constituents but glutamine served as the control. The amount of enzyme added was to effect the synthesis of about I $\mu$ mole of $\gamma$-glutamylhydroxamic acid in $15 \mathrm{~min}$. The conditions for incubation and color development for the transferase activity were the same as for the synthetase activity.

Protein was estimated by the method of Lowny et al. ${ }^{12}$ with crystalline bovine albumin as the standard.

\section{Materials}

All compounds used in this investigation were purchased from commercial sources. All salts were reagent grade.

\section{RESULTS}

Table I summarizes the results of the purification for glutamine synthetase from rat liver. The procedure has yielded an enzyme preparation with a specific activity IIo times that of the homogenate. The enzyme preparation lost $I 7$ and $39 \%$ of its activity, respectively, in Io and 40 days at $-30^{\circ}$.

TABLE I

PURIFICATION OF GLUTAMINE SYNTHETASE FROM RAT LIVER

\begin{tabular}{|c|c|c|c|c|c|}
\hline Step & $\begin{array}{c}\text { Volume } \\
(m l)\end{array}$ & $\begin{array}{c}\text { Protein } \\
\text { concentration } \\
(m g / m l)\end{array}$ & $\begin{array}{c}\text { Specific } \\
\text { activity } \\
\text { (units/mg } \\
\text { protein) }\end{array}$ & $\begin{array}{c}\text { Total } \\
\text { activity } \\
\text { (units) }\end{array}$ & $\begin{array}{c}\text { Yield } \\
(\%)\end{array}$ \\
\hline Homogenate & 125 & 45.0 & I. 36 & 7520 & (10o) \\
\hline $\mathrm{NaCl}$ & ro3 & I0.0 & 6.88 & 7080 & 94.I \\
\hline$\left(\mathrm{NH}_{4}\right)_{2} \mathrm{SO}_{4}$ & 30.8 & 13.8 & 13.5 & $575^{6}$ & 76.5 \\
\hline $\mathrm{pH}$ & I 5.2 & 2.0 & I34 & 4076 & 54.2 \\
\hline Dialysate & I6.I & $\mathbf{1} .6$ & 149 & $3^{8} 31$ & 50.9 \\
\hline
\end{tabular}

\section{Effect of metal ions}

Preliminary experiments with the microsomal enzyme from rat liver have indicated some relationship between the inhibitory effect of metal ions and the cysteine concentration. These experiments have been extended with the partially purified enzyme preparation. Metal ions were added to the reaction mixture containing $\mathbf{M g}^{2+}$ in the presence and in the absence of cysteine, and the enzyme activities in the two situations were compared. The results in Table II give such a comparison. The activities obtained with and without cysteine in the reaction mixture were both designated as $100 \%$, although the activity in the latter amounted to about $50 \%$ of that in the 
former. Based on their effect on the enzyme, the metal ions may be classified into three groups: (a) those that showed no inhibition irrespective of the cysteine concentration, such as $\mathrm{Al}^{3+}, \mathrm{Cr}^{3+}$, and $\mathrm{Ni}^{2+}$; (b) those that inhibited the enzyme activity to the same extent, regardless of the cysteine concentration, such as $\mathrm{Ca}^{2+}$ and $\mathrm{Mn}^{2+}$; (c) those whose inhibition depended on the cysteine concentration, such as $\mathrm{Fe}^{2+}$, $\mathrm{Fe}^{3+}, \mathrm{Co}^{2+}, \mathrm{Cu}^{+}, \mathrm{Cu}^{2+}, \mathrm{Zn}^{2+}, \mathrm{Cd}^{2+}$ and $\mathrm{Hg}^{2+}$. $\mathrm{Mn}^{2+}$ was extremely inhibitory despite the presence of 80 times its concentration of $\mathrm{Mg}^{2+}$. Only $\mathrm{Fe}^{3+}$ exhibited a greater inhibition in the presence of cysteine than in its absence. The inhibition by $\mathrm{Cd}^{2+}$ and $\mathrm{Hg}^{2+}$ showed the greatest dependence on the cysteine concentration, closely followed by $\mathrm{Cu}^{+}, \mathrm{Cu}^{2+}$, and $\mathrm{Zn}^{2+}$.

The results suggest that the formation of a metal mercaptide bond in the protein may have caused the observed inhibition. But an examination of the sability constants $^{13}$ of the complexes of some of these metals with cysteine shows no correlation of the magnitude of the constants with the extent of inhibition by the metal ions. Conceivably, the sulfhydryl group in a protein and that of cysteine may yield quite different stability constants with a given metal ion. In the experiments described above the molar ratio of cysteine to metal ion was held constant at roo. In the following experiments, the concentration of the metal ion remained at $0 . I I \mathrm{mM}$, while

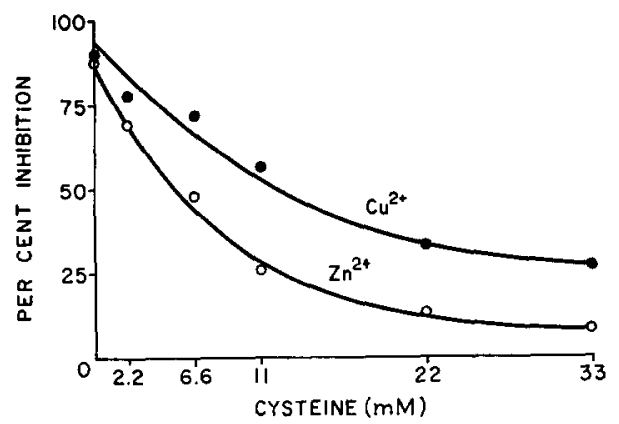

Fig. I. Relation of inhibition of glutamine synthetase by $\left.\mathrm{Cu}^{2+}(-)\right)$ and $\mathrm{Zn}^{2+}(\mathrm{O}-\mathrm{O})$ to the concentration of cysteine. The concentration of the metal ions was maintained at o.I I $\mathrm{mM}$.

the concentration of cysteine varied. Fig. I shows the relation of the degree of inhibition by either $\mathrm{Zn}^{2+}$ or $\mathrm{Cu}^{2+}$ to the concentration of cysteine. We can see that inhibition by the metal ions decreased as the concentration of cysteine in the reaction mixture increased. At the highest concentration of cysteine shown in the figure, namely $0.033 \mathrm{M}$, the inhibition by $\mathrm{Zn}^{2+}$ was almost completely prevented. Under the same conditions, however, the inhibition by $\mathrm{Cu}^{2+}$ was prevented to a lesser extent. Replacing cysteine with BAL, at much lower concentrations, yielded similar results.

\section{Interrelationship between $\mathrm{Mn}^{2+}$ and $\mathrm{Mg}^{2+}$}

Since $\mathrm{Mn}^{2+}$ exhibited its inhibitory effect on the enzyme activity in the presence of $\mathrm{Mg}^{2+}$ (Table II), this effect has been examined further. A series of experiments was made in which the $\mathrm{Mn}^{2+}$ effect was determined at various $\mathrm{Mg}^{2+}$ concentrations. Fig. 2 
TABLE II

EFFECT OF METAL IONS ON GLUTAMINE SYNTHETASE ACTIVITY IN THE PRESENCE AND IN THE ABSENCE OF CYSTEINE

The reaction mixture always contained $8.8 \mathrm{mM} \mathrm{MgCl}_{2}$. Cysteine, when present, was 0.0 I I $\mathrm{M}$. The concentration of the salt was 0.1 I mM.

\begin{tabular}{|c|c|c|}
\hline \multirow[b]{2}{*}{ Addition } & \multicolumn{2}{|c|}{ Synthetase activity } \\
\hline & $\begin{array}{c}\text { Cysteine added } \\
(\%)\end{array}$ & $\begin{array}{c}\text { Cysteine om } \\
(\%)\end{array}$ \\
\hline None & IOO.0 & 100.0 \\
\hline $\mathrm{AlCl}_{3}$ & 98.8 & 98.0 \\
\hline $\mathrm{CaCl}_{2}$ & 81.8 & 84.1 \\
\hline $\mathrm{CrCl}_{3}$ & 107 & I I9 \\
\hline $\mathrm{MnCl}_{2}{ }^{*}$ & 19.0 & 28.0 \\
\hline $\mathrm{FeSO}_{4}$ & 36.7 & 16.7 \\
\hline $\mathrm{FeCl}_{3}$ & 44.0 & 76.9 \\
\hline $\mathrm{CoCl}_{2}$ & IOI & 80.8 \\
\hline $\mathrm{NiCl}_{2}$ & 96.9 & 91.7 \\
\hline $\mathrm{CuCl}$ & 73.5 & o \\
\hline $\mathrm{CuSO}_{4}$ & 66.8 & 5.0 \\
\hline $\mathrm{ZnSO}_{4}$ & 84.2 & 12.6 \\
\hline $\mathrm{Cd}\left(\mathrm{NO}_{3}\right)_{2}$ & I I3 & 4.0 \\
\hline $\mathrm{HgCl}_{2}$ & 100 & o \\
\hline
\end{tabular}

* Both $\mathrm{MnCl}_{2}$ and $\mathrm{MnSO}_{4}$ purchased from three chemical companies yielded similar results.

shows the enzyme activity obtained under different conditions and expressed as a percentage of that assayed under the standard conditions ${ }^{4}$. At extremely low concentrations of $\mathrm{Mg}^{2+}$, i.e., below I.o mM, $\mathrm{Mn}^{2+}$ showed a very mild stimulation. When the $\mathrm{Mg}^{2+}$ concentration reached the neighborhood of $2.0 \mathrm{mM}$, significant stimulation by $\mathrm{Mn}^{2+}$ was apparent. But, as the $\mathrm{Mg}^{2+}$ concentration rose further, $\mathrm{Mn}^{2+}$ became

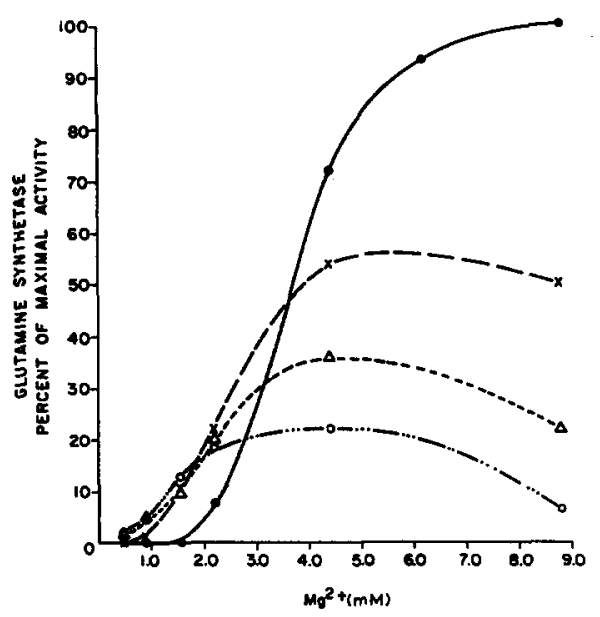

Fig. 2. Dependence of $\mathrm{Mn}^{2+}$ inhibition of glutamine synthetase on $\mathbf{M g}^{2+}$ concentration. The graph shows the enzyme activity in the absence of $\mathrm{Mn}^{2+}(-)$, and in the presence of $0.022 \mathrm{mM}$ $(x-x), 0.066 \mathrm{mM}(\Delta-\Delta)$, and $0.13 \mathrm{mM}(\mathrm{O}-\mathrm{O}) \mathrm{Mn}^{2+}$. Cysteine was maintained at I I $\mathrm{mM}$ in all experiments. 
inhibitory. The inhibition was greater with higher concentrations of $\mathrm{Mn}^{2+}$ and also with higher concentrations of $\mathrm{Mg}^{2+}$. For instance, with a concentration of o.13 $\mathrm{mM}$, $\mathrm{Mn}^{2+}$ lowered the synthetase activity by $93.5 \%$ (from roo to $6.5 \%$ ) at a $\mathrm{Mg}^{2+}$ concentration of $8.8 \mathrm{mM}$, but it only reduced the activity by $50.0 \%$ (from 72.0 to $22.0 \%$ ) at a $\mathrm{Mg}^{2+}$ concentration of $4.4 \mathrm{mM}$.

\section{$M n^{2+}$ requirement of $\gamma$-glutamyltransferase}

Since $\gamma$-glutamyltransferase in green peas ${ }^{2}$ and sheep brain ${ }^{8}$ had been shown to be activated by $\mathrm{Mn}^{2+}$ and, to a lesser extent, by $\mathrm{Mg}^{2+}$, the cation requirement of this enzyme activity in the partially purified preparation from rat liver was investigated. The transferase activity required $\mathrm{Mn}^{2+}$; no activity occurred, when $\mathrm{Mn}^{2+}$ was replaced by $\mathrm{Mg}^{2+}, \mathrm{Ca}^{2+}, \mathrm{Co}^{2+}, \mathrm{Ni}^{2+}, \mathrm{Cu}^{2+}$, or $\mathrm{Cd}^{2+}$. Hence, in rat liver the synthetase and the transferase showed an absolute requirement for $\mathrm{Mg}^{2+}$ and $\mathrm{Mn}^{2+}$, respectively.

\section{Abolishing the sulfhydryl requirement by ligands}

Since certain metal ions were inhibitory to the synthetic reaction and their inhibition depended on the concentration of a thiol, the possibility that other organic ligands might also influence the sulfhydryl requirement of the enzyme was next examined. A mixture of the enzyme and a ligand with $\mathrm{pH}$ adjusted to about 7.0 was

\section{TABLE III}

RELATIVE EFFECTIVENESS OF LIGANDS IN ABOLISHING THE SULFHYDRYL REQUIREMENT OF GLUTAMINE SYNTHETASE

Mixtures of the enzyme and the ligands, whose final concentrations are given below, were kept at $5^{\circ}$ for $\mathrm{I} h$. Aliquots of the mixtures were subsequently assayed for the enzyme activity. The activity assayed without cysteine is expressed as a percentage of that assayed with o.OI I M cysteine (the maximal activity). This percentage value determines the effectiveness of the ligand. The concentrations of the ligands during assay were usually less than one tenth of those given below.

\begin{tabular}{|c|c|c|c|}
\hline (gi & $\begin{array}{l}\text { Ineffective } \\
\text { (giving wp to } 66 \% \text { of } \\
\text { he maximal activity) } \\
(m M)\end{array}$ & $\begin{array}{c}\text { Partially effective } \\
\text { (giving 66-95\% of } \\
\text { the maximal activity) } \\
(\mathrm{mM})\end{array}$ & $\begin{array}{c}\text { Fully effective } \\
\text { (giving } 96-100 \% \text { of } \\
\text { the maximal activity) } \\
(\mathrm{mM})\end{array}$ \\
\hline Oxalic acid & 2.5 & & \\
\hline Citric acid & & 2.5 & \\
\hline Salicylic acid & 5.0 & & \\
\hline Nicotinic acid & 5.0 & & \\
\hline Sarcosine & 5.0 & & \\
\hline Choline chloride & 5.0 & & \\
\hline tert.-Butylamine & & 2.5 & \\
\hline Dimethylamine & 2.5 & & \\
\hline Trimethylamine & 2.5 & & \\
\hline Ethylenediamine & & 2.5 & \\
\hline Nitrilotriacetic acid & $2.5 \cdot 10^{-2}$ & & $2.5 \cdot 10^{-1}$ \\
\hline Nitrilotriethanol & $5.0 \cdot 10^{-1}$ & & \\
\hline EDTA & $5.0 \cdot 10^{-5}$ & $5.0 \cdot 10^{-3}$ & $5.0 \cdot 10^{-2}$ \\
\hline HEDTA & & $5.0 \cdot 10^{-2}$ & $2.5 \cdot 10^{-1}$ \\
\hline 8-Hydroxyquinoline & & $2.5 \cdot 10^{-1}$ & 2.5 \\
\hline I, Io-phenan throline & $2.5 \cdot 10^{-2}$ & & $2.5 \cdot 1 \mathrm{O}^{-1}$ \\
\hline$\alpha, \alpha^{\prime}$-Dipyridyl & & 2.5 & \\
\hline
\end{tabular}


allowed to stand at $5^{\circ}$ for $\mathrm{I} h$. An aliquot of the mixture was subsequently assayed for the enzyme activity in the presence and in the absence of cysteine. The enzyme alone, i.e. without the ligand, was assayed under the same conditions; this served as the control. In practice, mixtures containing graded concentrations of a ligand were prepared and assayed, but the highest concentration used did not exceed $5.0 \mathrm{mM}$. The concentration of the enzyme in the mixtures was held constant and corresponded to an activity of about 30 units $/ \mathrm{ml}$. In the presence of cysteine, mixtures of the enzyme and ligands always yielded the same activity as the enzyme alone, showing that the ligands within the concentrations used did not affect the enzyme activity. But when cysteine was omitted, an enzyme-ligand mixture could yield an activity equal to or higher than that of the enzyme alone. If the activity of the mixture and that of the enzyme were equal, the ligand, at the concentration used, was considered ineffective in abolishing the sulfhydryl requirement. On the other hand, if the activity of the mixture assayed without cysteine attained the same value as that assayed with cysteine, the ligand, at the concentration used, was considered fully effective in eliminating the sulfhydryl requirement of the enzyme.

Table III shows the results of these experiments. About one half of the ligands tested showed ineffectiveness in eliminating the sulfhydryl requirement. Several carboxylic acids and a few amines constituted this group. To a degree the concentration of a ligand determined its effectiveness. The ligands that were fully effective at one concentration could be made ineffective by successive dilutions. The most effective ligands included EDTA, HEDTA, nitrilotriacetic acid, and I, Io-phenanthroline, although citric acid, tert.-butylamine, ethylenediamine, and $\alpha$,'-dipyridyl also showed partial effectiveness at $2.5 \mathrm{mM}$. No correlation appears to exist between the ability of a ligand to abolish the sulfhydryl requirement and its chemical structure. But the effective ligands usually yield higher stability constants with most metal ions than the ineffective ones ${ }^{13}$.

\section{Dependence of arsenite inhibition*}

Trivalent arsenicals react specifically with sulfhydryl groups in biological systems.

TABLE IV

DEPENDENCE OF THE INHIBITION OF GLUTAMINE SYNTHETASE BY ARSENITE ON THE DITHIOLS

\begin{tabular}{|c|c|c|c|}
\hline \multirow{3}{*}{ Thiol added } & \multicolumn{3}{|c|}{ Per cent inhibition } \\
\hline & \multicolumn{3}{|c|}{ Arsenite (mM) } \\
\hline & $0 . I I$ & 0.44 & I.I \\
\hline None & & 7.0 & 10.5 \\
\hline Cysteine, I.I mM & & & 13.5 \\
\hline Cysteine, I I mM & & o & 8.0 \\
\hline 2-Mercaptoethanol, i I mM & & I.6 & 8.4 \\
\hline GSH, I I mM & & & 11.7 \\
\hline I,3-Dimercaptopropane, $2.2 \mathrm{mM}$ & & I7.6 & $24 \cdot 4$ \\
\hline BAL, 0.1 I mM & $53 \cdot 5$ & 59.0 & \\
\hline BAL, I.I mM & 9.0 & 37.0 & 85.5 \\
\hline 2,5-Dimercapto-1,3,4,-thiodiazole, $0.66 \mathrm{mM}$ & & 2.0 & 6.1 \\
\hline
\end{tabular}

* A brief report of this work has appeared in Abstr., 6th Internatl. Congr. Biochem., New York, 1964, p. 344 . 
Their affinity for dithiols with closely adjacent sulfhydryl groups has been useful for detecting such structures in enzymes. Sodium arsenite inhibited the synthetase, but the inhibition depended on the presence of a dithiol. Table IV shows the results. Arsenite did not inhibit significantly the enzyme in the absence of an added thiol or in the presence of a monothiol. In the presence of I,3-dimercaptopropane, arsenite showed a mild but significant inhibition. The inhibition was by far the greatest in the presence of BAL. With I.I mM BAL, the inhibition increased from 9.0 to $85.5 \%$, as the molar ratio of arsenite to BAL increased from 0.I to I.o. The same molar ratio of I.O, however, produced only $53.5 \%$ inhibition, when the concentration of BAL was lowered to o.II mM. Thus, BAL appeared to act as a mediator in arsenite inhibition, although excess BAL reversed it. 2,5-Dimercapto-I,3,4-thiodiazole, although a dithiol, was ineffective in fulfilling the sulfhydryl requirement of the enzyme; arsenite was also not inhibitory in its presence. Presumably, only the dithiols that activate the enzyme can mediate arsenite inhibition.

\section{Effect of other sulfhydryl reagents}

In addition to the metal ions and arsenite, the inhibitory effect of a few other sulfhydryl reagents on rat-liver glutamine synthetase was examined. p-Chloromercuribenzoate has been shown to be an inhibitor of glutamine synthesis in sheep

TABLE V

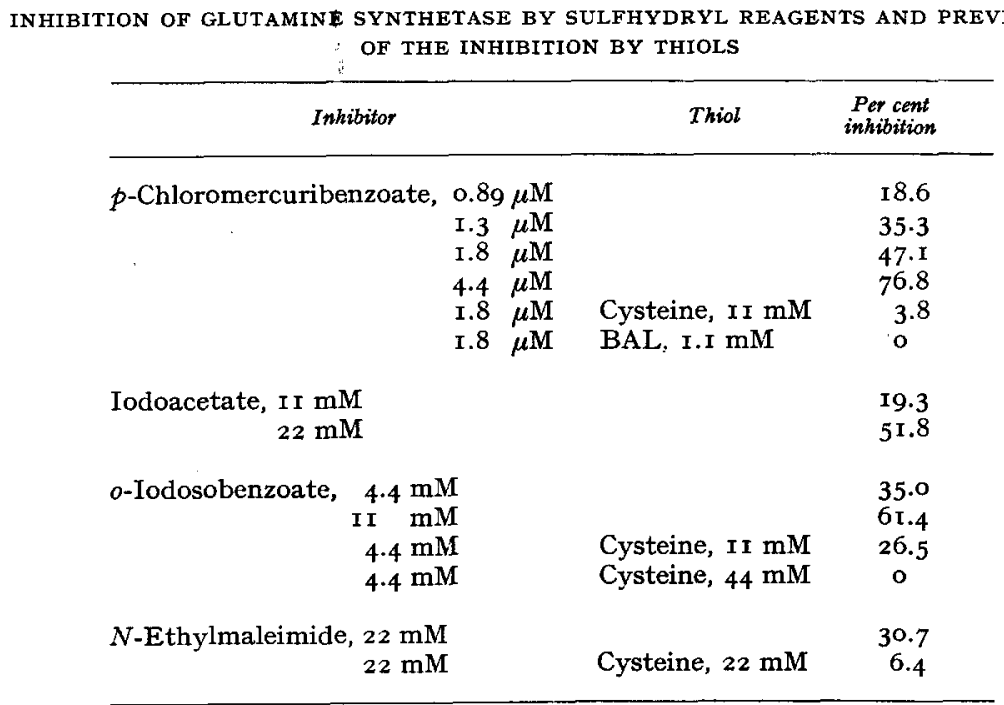

brain $^{7}$, green peas ${ }^{2}$, and bacteria ${ }^{9}$. This compound also exerted a potent inhibition on the rat liver enzyme, and its inhibition could be prevented completely by a thiol (Table V). Both iodoacetate and $o$-iodosobenzoate inhibited the synthetase, the latter being nearly three times as potent as the former. Cysteine could prevent the inhibition by $o$-iodosobenzoate. Prevention of the iodoacetate inhibition by a thiol could not be 
tested, however, because the iodine formed on adding the $\mathrm{FeCl}_{3}$ reagent interfered with determination of the hydroxamic acid. On the other hand, $N$-ethylmaleimide mildly inhibited glutamine synthetase. The different degrees of inhibition noted here may suggest a difference in the relative affinity of the enzyme for the inhibitors.

\section{Inhibition by formamidine disulfide, thiourea, and cyanamide}

WALKER AND WALKER ${ }^{14}$ have shown that FDS inhibited sulfhydryl enzymes and that the inhibition could be prevented by cysteine. The results in Table VI show that glutamine synthetase was also sensitive to this compound. But without prior incubation of the enzyme with FDS, the inhibition was incomplete and appeared to have reached a plateau of $50-60 \%$, when the concentration of the inhibitor rose $20-$ fold. Under these conditions, BAL could prevent completely the inhibition by FDS, when the molar ratio of BAL to inhibitor was unity. BAL showed only $50 \%$ effectiveness

\section{TABLE, VI}

INHIBITION OF GLUTAMINE SYNTHETASE BY FORMAMIDINE DISULFIDE, THIOUREA, AND CYANAMIDE IN THE PRESENCE AND IN THE ABSENCE OF A THIOL

Two series of experiments were made with FDS. In one series, the inhibitor was added to the incomplete reaction mixture following BAL, when used, but preceding the enzyme. Immediately afterwards, the reaction was allowed to proceed by adding ATP. In another series, prior incubation of FDS with the enzyme was made at $37^{\circ}$ for 8 minutes before the addition of BAL, when used, and ATP. Both thiourea and cyanamide, however, were added without prior incubation.

\begin{tabular}{|c|c|c|c|c|c|}
\hline \multirow{3}{*}{ Inhibitor } & \multirow{3}{*}{$(m M)$} & \multicolumn{4}{|c|}{ Per cent inkibition } \\
\hline & & \multicolumn{2}{|c|}{ Without thiol } & \multicolumn{2}{|c|}{ With $B A L(0.22 \mathrm{mM})$} \\
\hline & & $\begin{array}{l}\text { No prior } \\
\text { incubation }\end{array}$ & $\underset{\text { incubation }}{\text { Priot }}$ & $\begin{array}{l}\text { No prior } \\
\text { incubation }\end{array}$ & $\underset{\text { incubation }}{\text { Prior }}$ \\
\hline \multirow[t]{8}{*}{ FDS } & 0.022 & & 85.5 & & \multirow{3}{*}{$\begin{array}{l}62.5 \\
\text { I9.7 (BAL, I.I mM) } \\
2.2(\mathrm{BAL}, 2.2 \mathrm{mM})\end{array}$} \\
\hline & 0.022 & & & & \\
\hline & 0.022 & & & & \\
\hline & O.I I & $3^{88.7}$ & 91.9 & 0.0 & 50.0 \\
\hline & 0.22 & 51.9 & 91.9 & 0.9 & 52.2 \\
\hline & I.I & 54.8 & 91.9 & 26.5 & 87.8 \\
\hline & 2.2 & $57 \cdot 5$ & & 54.1 & \\
\hline & $4 \cdot 4$ & 58.9 & & $65 \cdot 3$ & \\
\hline \multirow[t]{3}{*}{ Thiourea } & 8.9 & 9.5 & & 8.0 & \\
\hline & 22.2 & $27 \cdot 4$ & & 24.5 & \\
\hline & 44.4 & $5^{8.9}$ & & 55.1 & \\
\hline \multirow[t]{3}{*}{ Cyanamide } & $5 \cdot 3$ & $27 \cdot 4$ & & $4 \mathrm{I} .8$ & \\
\hline & 10.6 & 38.4 & & 57.2 & \\
\hline & 21.2 & 56.2 & & $67 \cdot 3$ & \\
\hline
\end{tabular}

when the ratio became 0.2 , and ineffectiveness when the ratio further fell to 0.1 . The results indicate that, although raising the concentration of the inhibitor did not enhance its inhibition appreciably, the system with an excess of the inhibitor did require additional BAL for protection. On the other hand, prior incubation of the enzyme with FDS greatly increased the potency of the inhibitor and decreased the 
effectiveness of BAL in reversing the inhibition subsequently. Thus, o.I I mM FDS produced an almost complete inhibition of the enzyme, and it took $2.2 \mathrm{mM}$ BAL to reverse, the inhibition caused by $0.022 \mathrm{mM}$ FDS.

Since FDS is an unstable compound and decomposes at physiologic $\mathrm{pH}$ presumably to thiourea, cyanamide, and sulfur ${ }^{15}$, the possibility that its decomposition products might be the actual inhibitors has been considered. As can be seen in Table VI, thiourea inhibited the synthetase only at very high concentrations, and the inhibition was independent of BAL. Cyanamide caused inhibition at slightly lower concentrations than thiourea, and the inhibition appeared to have been somewhat aggravated by BAL. These results have demonstrated that the inhibition by neither thiourea nor cyanamide can account for the inhibitory effect of FDS.

\section{DISCUSSION}

Despite the precautions taken in the purification procedure, contamination of the enzyme preparation with extraneous metal ions remains a distinct possibility, especially since the enzyme was only partially purified. However, the prevention of inhibition of certain metal ions by a thiol and the ability of certain ligands to abolish the sulfhydryl requirement of the enzyme would suggest that the synthetase may contain a metal ion and that the metal ion may be bound to sulfhydryl group. The inhibitory effect of an added metal ion may result from a displacement reaction between the metal ion and the one originally bound to the enzyme. Moreover, the bound metal ion appears to be not only non-essential to the enzyme activity but actually inhibitory to it, since treatment with certain ligands lowers or abolishes the sulfhydryl requirement. Certainly, the question of metal binding can only be settled by a vigorous testing procedure with a highly purified enzyme preparation.

Although partial activation by $\mathrm{Mn}^{2+}$ has been observed for glutamine synthetase from sheep brain ${ }^{7,8}$, pigeon liver ${ }^{6}$, armyworms ${ }^{10}$, green peas ${ }^{2}$, and bacteria ${ }^{9,16}, \mathrm{Mn}^{2+}$ is extremely inhibitory for the enzyme from rat liver. The failure of $\mathrm{Mg}^{2+}$ at very low concentrations to activate the enzyme could be due to the preferential binding of $\mathrm{Mg}^{2+}$ to other substances in the enzyme preparation. Hence, the stimulatory effect of $\mathrm{Mn}^{2+}$ at the low concentrations of $\mathrm{Mg}^{2+}$ could result from the greater affinity of these substances for $\mathrm{Mn}^{2+}$, thereby setting the $\mathrm{Mg}^{2+}$ free for the synthetic reaction. Furthermore, since the lowest molar ratio of ATP to $\mathrm{Mn}^{2+}$ in the reaction mixture was 34, the inhibition by $\mathrm{Mn}^{2+}$ could not have been caused by its binding to ATP. The ratliver enzyme deserves further study with respect to $\mathrm{Mn}^{2+}$ inhibition.

The inhibition of a number of enzymes by trivalent arsenicals and the relation of the inhibition to the presence of a thiol have been observed by many investigators. Thus, STOCKen AND THOMPSON ${ }^{17}$ showed that organic arsenoxides and sodium arsenite inhibited pyruvate oxidase of pigeon brain, and that the inhibition could be prevented by dithiols, especially BAL, but not by monothiols. They ${ }^{\mathbf{1 8}}$ postulated that the arsenicals formed a stable ring with two sulfhydryl groups closely placed in space on the protein molecule. In other instances, the inhibition by sodium arsenite depended on the presence of a reduced substrate, such as in lipoyl dehydrogenase ${ }^{19}$, a monothiol, such as in aldehyde dehydrogenases ${ }^{20}$, or a dithiol, such as in $\beta$-hydroxybutyric dehydrogenase ${ }^{21}$ and in enzymes of oxidative phosphorylation ${ }^{22}$. The results presented in this study have shown the dependence of arsenite inhibition of glutamine synthe- 
tase on the presence of an active dithiol and suggest the presence of a dithiol component in the enzyme. This suggestion is consistent with an earlier observation ${ }^{4}$ that, on a molar basis, BAL was roo times as active as cysteine for the enzyme from rat liver.

$\mathrm{JACOBY}^{20}$ has suggested that the requirement for a thiol in arsenite inhibition was due to the need for reducing a disulfide group before arsenite could react. On the other hand, FLUHARTY AND SANADI ${ }^{22}$ have proposed that BAL served as a vehicle in transporting arsenite to the sensitive dithiol group located in a hydrophobic region. Since inhibition of glutamine synthetase by arsenite did not occur in the presence of a monothiol, the assumption that the dithiol is required merely to reduce a disulfide group in the enzyme seems improbable. On the other hand, the requirement for a dithiol may be relative and dependent on the conformation of the protein molecule in the region where the reactive dithiol component is located. If the conformation in this region can be modified, such as by a sulfhydryl reagent, the need for a dithiol to mediate arsenite inhibition may be eliminated.

The inability of FDS to inhibit the synthetase completely without antecedent incubation would appear to suggest that, although certain sulfhydryl groups in the enzyme are vulnerable to FDS, others by virtue of the groupings in their vicinity are not readily accessible to FDS but can be protected by BAL despite an excess of the inhibitor. Possibly, glutamine synthetase contains in addition to one dithiol component, other reactive sulfhydryl groups.

\section{ACKNOWLEDGEMENTS}

This work was supported in part by research grants, CA-oI7I9 and AM-073I9, from the National Cancer Institute and the National Institute of Arthritis and Metabolic Diseases, U.S. Public Health Service.

\section{REFERENCES}

1 C. Wu, Arch. Biochem. Biophys., in the press.

2 W. H. Elliott, J. Biol. Chem., 201 (I953) 66I.

${ }^{3}$ L. Levintow And A. Meister, J. Biol. Chem., 209 (I954) 265.

4 C. Wu, Comp. Biochem. Physiol., 8 (1963) 335.

5 J. F. Speck, J. Biol. Chem., I79 (I949) I 387.

- J. F. SPECK, J. Biol. Chem., I 79 (I949) I 405.

7 W. H. Elliotr, Biochem. $J ., 49$ (I95I) ro6.

B J. Greenberg and N. Lichtenstein, J. Biol. Chem., 234 (1959) 2337.

$\theta$ B. A. FRY, Biochem. J., 59 (I955) 579.

10 L. Levenbook and J. Kunn, Biochim. Biophys. Acta, 65 (1962) 219.

11 C. WU, Biochim. Biophys. Acta, 77 (1963) 482.

12 O. H. Lowry, N. J. Rosebrough, A. L. Farr and R. J. Randall, J. Biol. Chem., I93 (I95I) 265.

13 J. Bjerrum, G. Schwarzenbach and L. J. Sillèn, Stability Constants, Part I, The Chem. Soc., Burlington House, London, 1957.

14 J. B. Walker and M. S. Walker, Arch. Biochem. Biophys., 86 (1960) 80.

15 G. Toennies, J. Biol. Chem., I20 (I937) 297.

16 C. Gomez Leonard, R. D. Housewright, and C. B. Thorne, Biochim. Biophvs. Acta, 62 (I962) 432 .

17 L. A. Stocken and R. H. S. Thompson, Biochem. J., 40 (1946) 535.

18 L. A. Stocken and R. H. S. Thompson, Biochem. J., 40 (1946) 529.

19 V. Massey and C. Veeger, Biochim. Biophys. Acta, 40 (1960) 184 .

20 W. B. JАCOBY, Arch. Biochem. Biophys., 70 (I957) 625.

21 I. Sekuzu, P. Jurtshuk, JR. ANd D. E. Green, J. Biol. Chem., 238 (I963) 975.

22 A. I. Flumarty and D. R. Sanadi, J. Biol. Chem., 236 (I96r) 2772. 